\title{
オースフォーミングによるマルテンサイト 強化機構に関する一考察
}

\section{五户勇雄 ${ }^{*}$ 木原諄二* 岸輝 雄 ${ }^{* *}$}

Isao Gokyu, Junji Kihara and Teruo Kishi: The Strengthening Mechanism of Ausformed Martensitic Steel. A number of investigations have been performed on the strengthening mechanism of ausformed martensite, and the following mechanisms have been proposed:

(1) Direct transfer of work-hardening structure from austenite to martensite.

(2) Dispersion hardening due to micro carbide precipitation.

(3) Decrease of martensite-plate size.

(4) Decrease of residual austenite.

(5) Production of twined martensite.

In this investigation, 4340-steel is ausformed in the metastable austenite-temperature range at high strain rates $\left(10^{2} \sim 10^{3} / \mathrm{sec}\right)$ by a counterblow forging tester, and the flow stress of the ausformed austenite at the working condition and the hardness of the ausformed martensite are measured. The following relation is obtained:

$$
\ddot{M}_{\mathrm{H}}=M_{\mathrm{H}}^{0}+3 A \sigma,
$$

where $M_{\mathrm{H}}$ is Vickers' hardness of the ausformed martensite, $A \sigma$ is the flow stress of the ausformed austenite at the ausforming condition and $M_{\mathrm{H}}^{0}$ depends on both the chemical compositions and the prethermo-mechanical history of specimens. The factor, 3 , of $A \sigma$ represents that the work hardening is directly transferred from austenite to martensite. On the basis of detailed discussions, it is concluded that the strengthening mechanism of the ausformed martensite is a direct transfer of work hardening and the other mechanisms mentioned above have a secondary effects. Especially, the hardening due to micro-carbide precipitation does not contribute essentially to the ausform-strengthening of martensite.

(Received May 16, 1967)

\section{I. 鍺}

鋼のマルテンサイトの強度がオースフォーミングによつ て改善されることについて，これまで多くの研究がなされ て来た(1).このオースフォーミングのマルテンサイト強度 上犁の機構については，(1)加工硬化説，(2) 析出物説，(3)

* 東京大学工学部绐金学科 (Department of Metallurgy, Faculty of Engineering, University of Tokyo, Tokyo)

** 東京大学大学院 (Graduate Student, University of Tokyo, Tokyo)

(1) G. Thomas, D. Schmatz and W. Gerberich: High Strength Materials, edited by V.F.Zackay,(1964), 251.
マルテンサイト微細化説，(4) 残留オーステテイト減少説 などがあるが，主として(1)か(2)が問題となる。加工硬化 説は，オーステナイトが加工硬化しただけ，マルテンサイ トに受けつがれ，強度上昇するというのであり，析出物説 はオーステナイトが加工されるとき，たとえば $\mathrm{M}_{6} \mathrm{C}_{23}$ の ような炭化物が析出することにより，それがマルテンサイ

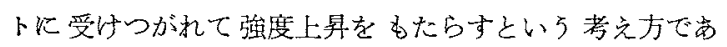
る。

著者らは，4340鋼を相打鍛造機(2)を用い，オースフォ ーミングした結果, オースフォーミングによるマルテンサ

（2）五今，木原：塑性と加工， 3(1962)，825. 
イトの強化はオーステナイトの加工硬化がマルテンサイト に受けつがれる “加工硬化説”によつて説明されるべきで あるという結論に達したので報告する。

\section{II. 実験}

\section{1. 実 験 試 料}

実験試料は 4340 鋼 (JIS SNCM 8) であるが，溶解ロット の違い, 熱拈よび加工履歴の違いで Table 1 のよ5に 3 種類となつた。

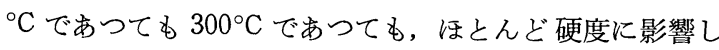
ていないことがわかる，ただ，保持時間の長い方がやや硬 度が低くなる傾向が認められる程度である。

Fig.4 はオースフォーミングの加工度と焼入れ後の硬度 との関係を示している.これから，オーステナイト化温度 によらず，加工度が 0.3 から 0.4 になると硬度に対する加 工度の影響が 飽和してくることがわかる，なお， Fig.5 は, オースフォーミングし，焼入れたものの焼戻し温度と 硬度との関係を示したものであるが，500 C まではオ一ス

Table 1 Chemical compositions and thermo-mechanical history.

\begin{tabular}{|c|c|c|c|c|c|c|c|c|c|}
\hline \multirow{2}{*}{ Sample } & \multicolumn{8}{|c|}{ Chemical composition (wt \%) } & \multirow{2}{*}{ Thermo-mechanical history } \\
\hline & $\mathrm{C}$ & $\mathrm{Si}$ & $\mathrm{Mn}$ & $\mathrm{P}$ & S & $\mathrm{Ni}$ & $\mathrm{Cr}$ & Mo & \\
\hline $\mathrm{A}$ & 0.40 & 0.32 & 0.78 & 0.013 & 0.010 & 1.76 & 1.00 & 0.21 & $12 \mathrm{~mm} \phi$ hot forged, $900^{\circ} \mathrm{C} \times 1 \mathrm{hr}$ annealed \\
\hline B & 0.37 & 0.25 & 0.74 & 0.011 & 0.011 & 1.79 & 0.76 & 0.23 & $13 \mathrm{~mm} \phi$ hot forged, $\begin{array}{l}800^{\circ} \mathrm{C} \times 30 \mathrm{~min} \text { annealed } \\
10.5 \mathrm{~min} \phi \text { cold swaged } \\
800^{\circ} \mathrm{C} \times 30 \mathrm{~min} \text { annealed } \\
9.5 \mathrm{~mm} \phi \text { cold drawn }\end{array}$ \\
\hline $\mathrm{C}$ & "I & "I & "I & "1 & "l & "I & "I & "I & $13 \mathrm{~mm} \phi$ hot forged, $900^{\circ} \mathrm{C} \times 1 \mathrm{hr}$ annealed in vacuo \\
\hline
\end{tabular}

これらの試料から，A と C 試料の場合には $10 \mathrm{~mm} \phi \times 10$

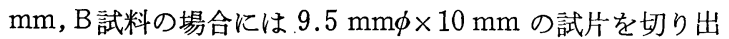
した.

\section{2. 実 験 方 法}

オーステナイト化温度に設定した炉で試片をオーステナ イト化した後, 加工温度に設定した鉛浴またはビスマスー鉛 浴に Quench し，それから加工温度に設定した 鍛造炉中に 移し，相打鍛造した．鍛造後，所定時間保持して，水焼入 れした，硬度はビッカース硬度計とミクロビッカース硬度 計を使用した。

変形中の flow stress は文献 (2) にある 方法, すなわち, ハンマーに貼布した抵抗線ひずみ計で荷重を，ハンマーの 腕にとりつけた平行板コンデンサの容量変化によつて変位 を測定した。

\section{III. 実 験 結 果}

Fig.1 は, オースフォームした後焼入れ, マルテンサイ トにしたものの硬度とオーステナイト化温度との関係であ る。焼戻し温度が $200^{\circ} \mathrm{C}$ の場合も $300^{\circ} \mathrm{C}$ の場合にも，才 一ステナイト化温度が高い汪ど, 硬度は低くなつているこ とがわかる。

Fig.2 は, オースフォームする前にオースフォーミング 温度に保持する時間と, 焼入れ後の硬度との関係である. この図から保持時間は焼入れ後の硬度に影響しないことが わかる.

Fig.3は, オースフォームをした後, オースフォーミン グ温度に保持する時間と, 焼入れ後の硬度との関係であ る.この図から保持時間は, 焼入れ後の焼戻し温度が 200

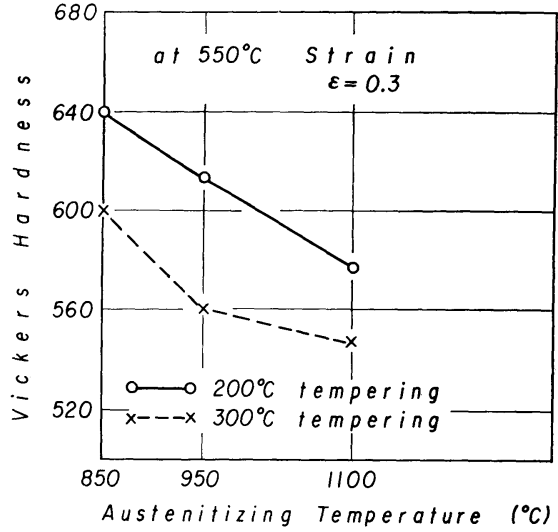

Fig.1 Effect of austenitizing temparature on vickers hardness. (B specimen)

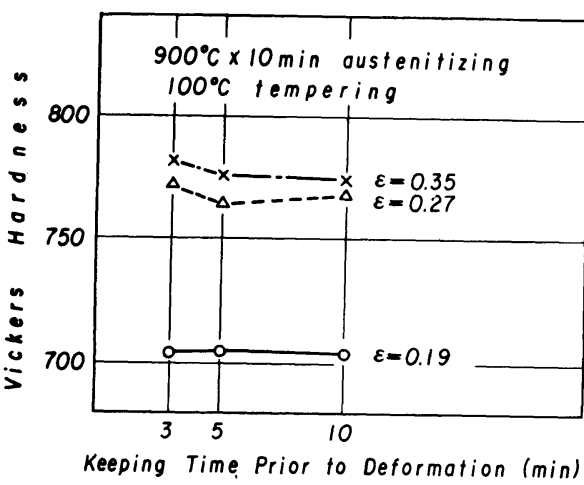

Fig.2 Effect of keeping time at $550^{\circ} \mathrm{C}$ prior to deformation on vickers hardness. (A specimen)

フォーミングの硬度に対する効果はそのまま残ることが羿 められる。 
Fig.6は, $550^{\circ} \mathrm{C}$ と $650^{\circ} \mathrm{C}$ に括いてオースフォーミング し焼入れた後の硬度と, オースフォーミングの際の変形抵

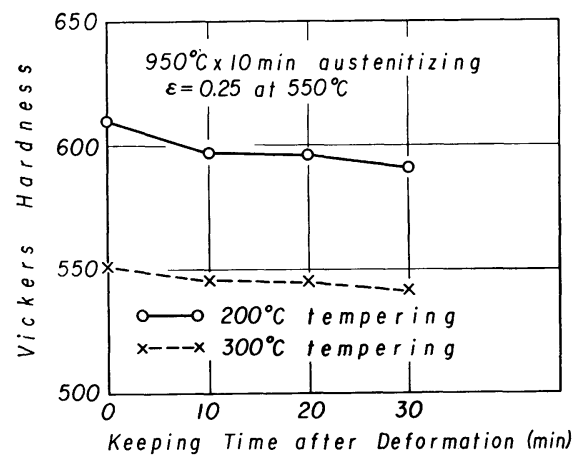

Fig.3 Effect of keeping time at $550^{\circ} \mathrm{C}$ after deformation on vickers hardness. (B specimen)

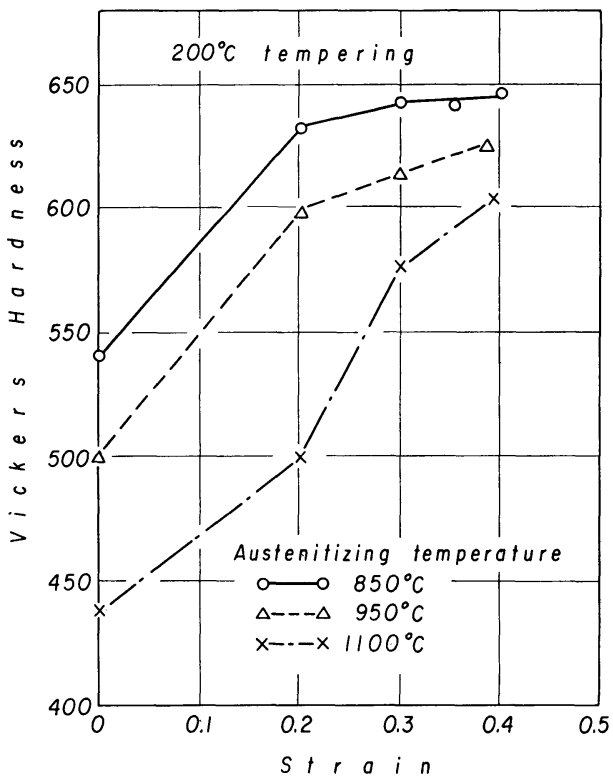

Fig.4 Relation between reduction and vickers hardness at various austenitizing temperature. (B specimen)

抗との関係である，Fig.6からわかることは，オースフォ 一ミング条件, すなわち, 温度, ひずみ速度のいかんを問 わず, オースフォーミングし焼入れた後の硬度は, オース フォーミング終了時のオーステナイトの強度と一意的な関 係があるということである.

\section{IV. 考察}

本実験による主要な結果はつぎのとおりである.

(1) オースフォーミングを行なら前に, オースフォーミ ング温度に保持する時間は，焼入れ後の硬度に影響を与え ない.

(2) オースフォーミング後, オースフォーミング温度に 保持する時間は，焼入れ後の硬度をやや少し低くする傾向

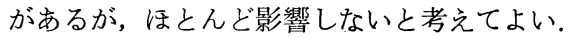

(3) ひずみ速度 102/sec の変形速度でオースフォーミ

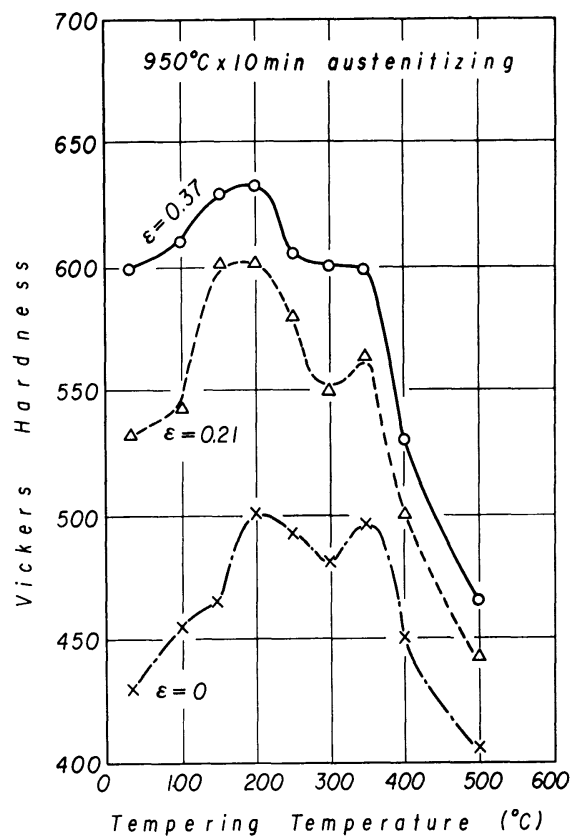

Fig.5 Variation of vickers hardness with tempering temparature. (B specimen)

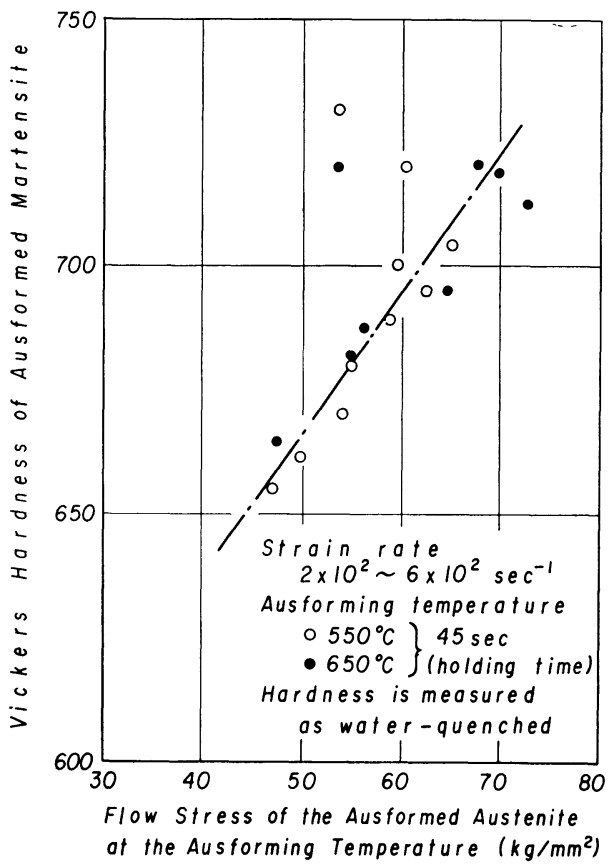

Fig.6 Relation between hardness of ausformed martensite and flow stress of the ausformed austenite at the ausforming temperature. (C specimen)

ソグをすると，硬度に対するオースフォーミング加工度の 影響は加工度 $0.3 \sim 0.4$ で飽和する傾向がある.

（4）オースフォーミングし焼入れた後の硬度は, オース 
フォーミング終了時の材料の強度により決まり, オースフ ォーミング温度沶よびそのひずみ速度の影響をうけない。

実験結果の (1) は, オーステナイト化温度から,オースフ ォーミング温度まで急冷した後, いわゆる S曲線の“bay” で保持している時間のうちに，オースフォーミング後焼入 れしたときの機械的性質に影響を与えるよ5な変化が過 冷オーステナイトに起こらないことを意味している，した がつてオースフォーミングのマルテンサイト硬度への影響 は,オースフォーミング温度に保持することによるのでな いことがわかる。

(2) は, オースフォーミングを終えてからオースフォー ミング温度に保持することは, 焼入れ後のマルテンサイト の硬度をやや減少させるということであるが，これは，こ のオースフォーミング温度に拈ける加工されたオーステナ イトの回復の影響によるものと思われる。したがつて， 4340 鋼のオースフォーミング 温度である $550^{\circ} \mathrm{C}$ では, 過 冷オーステナイトの加工後, 再結晶による完全な回復も, また加工によつて過冷オーステナイトに導入された格子欠 陷に基つ゚く炭化物の析出が，マルテンサイトの硬度に影響 を扣よぼすほどは起こらなかつたと考えられる。したがつ て，オースフォーミングによるマルテンサイトの強化は thermal な過程に 基づく炭化物の析出によるのでないと考 えられる。そこで，オースフォーミングによるマルテンサ イトの強化に, もし, 炭化物の析出が有効であるならば, その炭化物は，加工中に形成されたものでなければならな W.

実験結果 (3) は，高ひずみ 速度でオースフォーミングを すると，Zackayら (3)が，圧延によつて $80 \%$ 圧下しなけれ ば得られなかつたマルテンサイトの強度上昇を 30 ～40\% の加工度で達成できたということである。この事実は，ま ず, オースフォーミングのマルテンサイト強化が炭化物の 析出によるならば，この析出過程は拡散過程を伴なうもの ではないことを意味している．実験結果 (1) と (2) は応力付 加の状態に扣いて，すなわち加丁中に炭化物の析出がマル テンサイト強度に影響するように起こる可能性を否定して いない.さらにこの実験結果 (3) は炭化物の析出の有無を 決定するものではないが，高ひずみ速度で変形した方が， 小さい加工度でマルテンサイトの強化が可能だということ は，炭化物の析出がマルテンサイト強化に有効ならば，そ の析出過程は, athermalなものでなければならないとい うことがいえる。

しかしながら,この実験結果 (3) は, オースフォーミング によるマルテンサイトの強化は, オーステナイトの加工硬 化がマルテンサイトに引きつがれるという加工硬化説の立 場に立てば無理なく説明が可能である。すなわち，オース テナイトは面心立方晶であるから, 加工硬化状態は温度と ひずみ速度に依存する(4).われわれの 実験条件はZ Zackay

(3) J.C.Shyne, V.F.Zackay and D.J.Schmatz: Trans. Amer.Soc.Met., 52 (1960) ,346.

（4）たとえば五弓，木原：塑性と加工，6(1965),403.
ら(3)の条件に比べて,ひずみ速度が $10^{3}$ 倍早い. したがつて 加工硬化が小さいひずみで十分起こることが期待される.

実験結果 (1) (2) (3)は, オースフォーミングの強化機構 が，炭化物の析出によるのではなく，加工硬化の引きつぎ によると考劣る方が妥当であることを示しているが，実験 結果 (4) は, 加工硬化の引きつぎがマルテンサイト強化の主 役であることを決定的に示している，すなわち，マルテン サイトの硬度はオーステナイトを加工したときの flow stressにより一意的に決定されており，加工条件 (温度と ひずみ速度)によらない，このことは，炭化物の析出がた とえ, athermal に応力の作用によつて起こるとしても, $550 \mathrm{C}^{\circ}$ と $650^{\circ} \mathrm{C}$ の加工温度で同じだけ析出するとは考光 られないし，鋼中の炭化物にこのような性質のものはまだ 存在が確認されていないので，炭化物による強化説を否定 する事実である. Fig.6 からマルテンサイトのビッカース 硬度 $M_{\mathrm{H}}$ と，オーステナイトの 加工終了時の flow stress $A \sigma$ の間に,

$$
M_{\mathrm{H}}=M_{\mathrm{H}}^{0}+3 A \sigma
$$

の関係が拝められる. ここで $M_{\mathrm{H}}^{0}$ は $A \sigma=0$ に外插した ときの值であつて, オースフォームしない場合の硬度では ない. Fig. 6 の場合は $M_{\mathrm{H}}^{0}$ は 515 である. マルテンサイト のビッカース硬度がオーステナイトの加工終了時の flow stress の 3 倍と直線関係にあるということは, 興味深い事 実である、すなわち，ビッカース硬度はだいたい，降伏強 度の 3 倍といわれているので, このことは, マルテンサイ トの降伏強度の増大が，オーステナイトの加工硬化に基づ く flow stress の増大と全く等しいことを意味している.

$M_{\mathrm{H}}^{0}$ は, 材料の熱履歴や加工履歴, 化学成分によつて決 定される量である，すなわち，本実験に 使用した 4340 鋼 の 3 種の試料に打いてすべて焼入れマルテンサイトの硬度 レベルが異なるのはこの $M_{\mathrm{H}}^{9}$ が異なるためである，Fig.6 は, C-試料について求めた $M_{\mathrm{H}^{-}} A \sigma$ 関係である.つまり, オースフォームされたマルテンサイトの強度は, オースフ オ一ムしない場合のマルテンサイトの強度にオーステナイ トが加工硬化して得た強度上䒜が，そのまま増加分として 加わつたものである.

さて, オースフォーミングによるマルテンサイトの強化 機構としてマルテンサイト微細化説がある。 これは，才 ースフォーミングによつて生じたオーステナイト相の変形 帯によつて，マルテンサイトの成長が阻止されることによ るといわれている.Zackay ら (3)は,オースフォーミングし たマルテンサイトの降伏強度 $(\sigma)$ とマルテンサイト板の長 さ $(d)$ との間に

$$
\sigma=\sigma_{0}+k d^{-1 / 2}
$$

が成立することを見い出した。しかしながら(2)式に括け る $k$ の值は $6.3 \mathrm{~kg} / \mathrm{mm}^{3 / 2}$ であつて，この值は 鉄の下降伏 点の場合に比べて非常に大である，通常 $k$ は鉄の下降伏点 の場合 $2 \sim 3 \mathrm{~kg} / \mathrm{mm}^{3 / 2}$ であり, 著者らの二人の研究 ${ }^{(5)} に よ$

（5）五弓，木原：強度国際会議に講演, Preprint P.228. 
ると $2.6 \mathrm{~kg} / \mathrm{mm}^{3 / 2}$ がリューダース带伝播を伴な弓場合の 値で、リェーダース带伝播を伴なわない降伏の昜合（压縮試 験の場合) $1.1 \mathrm{~kg} / \mathrm{mm}^{3 / 2}$ であることが確かめられている。 さらに,マルテンサイトの板状結晶の長さが同じ場合でも， オースフォーミングの有無によつて強度が異なることが認 められて和り ${ }^{(6)}$, したがつて，オースフォーミングによる マルテンサイトの微細化による強度上昇は 2 次的なるので

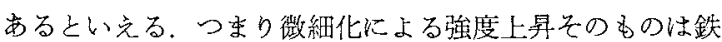

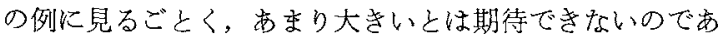
つて，マルテンサイトは微細化する一方，その内部が強化 されているのである。

Schmatzら(1)は, マルテンサイトのオースフォーミング による強化は、オーステナイトの加工硬化を受けつぐこと によるとしながら，な特オーステナイトの加工硬化に対 し，锟細炭化物が析出することが影響している可能性を考

(6) W.M.Justusson and D. J. Schmatz: ASM Trans. Quart, $55(1962), 640$.
克ているがわれわれの研究結果によれば，そのような微 細炭化物の析出がオーステナイト化温度から, $650^{\circ} \mathrm{C}$ に急 冷する間に起こつていなければならないことになる。この よ5なことは現在のところ考えることがでさない。

V. 桔

\section{論}

以上の実験結果に対する考察から，オースフォーミング のマルテンサイト強化は，オーステナイトの加工硬化を受 けつぐことによるのであつて，オースフォーミングによる マルテンサイトの 政細化は 2 次的効果を有するだけであ り，さらに炭化物の役割は考劣ることがでさないことが明 らかになつた。

終りに本研究を遂行するにあたり，当時東海大学学生で あつた山下伸也氏，藤野蜻郎氏の助力に感謝の意を表す る. 